\title{
A política de conciliação nos folhetins: Joaquim Manuel de Macedo e $A$ carteira do meu tio (1855)
}

\author{
The politics of conciliation in the serials: The my uncle's Wallet (1855), \\ by Joaquim Manuel de Macedo
}

\section{Carollina Carvalho R. de Lima ${ }^{1}$}

\section{RESUMO}

Em 1855, Joaquim Manuel de Macedo ofereceu ao público-leitor brasileiro um livro de viagem, cuja preocupação não era somente promover o divertimento de seus leitores, mas, principalmente, apresentar um quadro da situação política no país e da atuação dos homens públicos naquele contexto. A carteira do meu tio, portanto, com seu tom satírico, expunha a visão de Macedo sobre alguns temas importantes à época: a política de conciliação conduzida por Marquês de Paraná, o sistema representativo brasileiro e o comportamento da classe política no Brasil. Tendo em vista o impacto dessa obra na década de 1850 e seu esquecimento com o passar dos anos, este artigo analisa o relato do sobrinho-viajante, cujo teor parece ser ainda tão atual.

Palavras-chave: Joaquim Manuel de Macedo - A carteira do meu tio - Literatura de viagem - Sátira política - Política de siliação - Imprensa

\section{ABSTRACT}

In 1855, Joaquim Manuel de Macedo has offered to the public a book of journey, whose concern was to present a picture of the political situation in the country and the action of public men in that context, but also their amusement. The My uncle's Wallet, therefore, with a satirist tone, expounded Macedo's vision of some important issues at the time: the policy of conciliation conducted by the Marquis of Paraná, the representative system of Brazil and the behavior of the political class. Considering the impact of this work in the 1850s and its oblivion over the years, this article analyses the account of the nephew-traveler, whose content seems to be still so current

Keyword: Joaquim Manuel de Macedo - My uncle's Wallet - Voyage literature - Political satire - Reconciliation Policy - The Press 
Reconhecido como um escritor de romances melodramáticos, Joaquim Manuel de Macedo, na década de 1840, obteve sucesso entre a crítica e o público-leitor, com a publicação da célebre A Moreninha (1844), o Moço Loiro (1845), os Dois Amores (1848) e a Rosa (1849). Entretanto, sua produção não esteve restrita às histórias de amor, pelo contrário, Macedo foi um autor versátil que transitou por diferentes gêneros - teatro, sátira, crônica -, consagrando-se na imprensa periódica. Em 1855, no auge de sua carreira, Macedo surpreende seus leitores com uma obra irreverente, $A$ carteira do meu tio, que aliava a sátira política e o gênero de viagens, cujo objetivo não era fazê-los chorar por um amor impossível, mas suscitar a reflexão acerca da situação política do país, que assistia à implantação da política de conciliação, liderada pelo Marquês de Paraná.

Esse livro de viagem destoa - daquilo que o escritor já havia publicado - pelo tom debochado e pela naturalidade com a qual o sobrinho, seu personagem central, defende atos de corrupção e justifica alguns desvios de conduta. Além disso, no contexto da produção macediana, $A$ carteira do meu tio, representa, a nosso ver, uma virada temática interessante, pois Macedo, que àquela altura (meados dos anos de 1850) já havia consolidado sua carreira como literato, apresenta ao público uma narrativa bem diferente de seus folhetins românticos, mais próxima aos seus textos cronísticos, cuja crítica aos costumes da época eram uma constante.

A "descoberta" de um Macedo político, irônico e um crítico de seu tempo nos colocou as perguntas que norteiam este artigo: $O$ que levou o escritor, àquela altura de sua carreira, enveredar pela seara da sátira política? Qual era a visão de Macedo sobre a conciliação, liderada pelo Marquês de Paraná?

Joaquim Manuel de Macedo nasceu em 1820, dois anos antes da independência do Brasil, na, então, freguesia de Itaboraí - que em 1833 foi elevada à categoria de vila -, localizada próxima à Corte do Rio de Janeiro. A região foi um centro político administrativo para as áreas portuárias no curso do Rio Macacú, como o Porto de Caxias, Vila Nova, Sampaio e a Freguesia de Santo Antônio de Sá, e caracterizava-se pela produção de alguns provimentos, como feijão, farinha, açúcar e café. A vila de Itaboraí, segundo Macedo, estava cercada de uma natureza "grande e sublime" e dela provinham grandes homens, que "representavam papéis, que ninguém chamaria de secundário, na grande cena da política, na magistratura, na administração provincial, etc." (O OSTENSOR, 1845, p. 179-180).

As informações sobre a infância de Macedo são escassas: sabemos, a partir de seus biógrafos, que ele pertencia a uma família modesta, que seu pai era dono de uma botica e teria sido juiz substituto e vereador em alguns momentos. A fim de atender ao desejo paterno, Macedo formou-se em Medicina, mas não foi este ofício que lhe permitiu ascender socialmente. No ano de sua formatura, em 1844, o jovem escritor publicou A Moreninha, cujo sucesso foi imediato e decisivo para a carreira literária do jovem escritor de Itaboraí e para a formação de um público-leitor, ainda incipiente, mas receptivo aos romances nacionais. 
Desde então, Macedo passou a circular entre os meios letrados, consolidando-se como um proeminente homem de letras na Corte.

A notoriedade alcançada por Macedo, entre o público-leitor e figuras ligadas ao Estado, abriu-lhe portas no jornalismo, na política e no âmbito educacional. Em 1845, Macedo ingressou no Instituto Histórico Geográfico Brasileiro (IHGB), onde trabalhou por quase 37 anos. Macedo ao integrar o IHGB aproximou-se, ainda mais, dos círculos letrados da Corte e estreitou seus laços de amizade com Dom Pedro II, sobretudo, após 1849, ano em que o Instituto se transferiu para o Paço Imperial e a presença do Imperador passou a ser comum. Em virtude desse contato com o soberano e sua atuação como professor no Colégio D. Pedro II, ele foi convidado para lecionar, sem remuneração, História às princesas Isabel e Leopoldina, passando a ter livre acesso ao Paço e ao Palácio Real.

Além da carreira docente, nesta época, dedicou-se com afinco à vida política. Macedo era filiado ao Partido Liberal e concorreu, no pleito de 1850, a uma vaga na Assembleia Provincial do Rio de Janeiro, mas não conseguiu se eleger, ficando apenas como suplente; na legislatura seguinte (1852-1853), também não obteve a quantidade de votos suficiente, permanecendo na suplência. Finalmente, em 1854, consegue eleger-se como titular, cargo que ocupou por mais cinco anos.

Entre 1852 e 1853, a fim de difundir seus ideais políticos, tornou-se editor do jornal liberal A Nação, impresso em uma tipografia instalada por ele, ao lado de sua casa. De acordo com Galante Sousa, o periódico deu projeção política à Macedo, na medida em que criticava os atos do governo conservador e lançava as propostas liberais, sendo fundamental para que o escritor saísse das duas suplências e assumisse o cargo efetivo (SOUSA, 1963, p. 140).

Macedo, assim como outros políticos coevos, assumiu o "fardo do homem de letras" oitocentista, cuja responsabilidade era construir uma nacionalidade brasileira por meio da literatura. Nesse sentido, o século XIX foi um período notável para o campo das letras, pois a sociedade o via como uma arena privilegiada de intervenção política, responsável pela formação de uma opinião pública, cuja legitimidade se baseava, justamente, na ideia de que representaria o pensar e a vontade da maioria.

Tendo em vista o locus privilegiado que se constitui a cena literária e a força política em que os impressos se constituem, este artigo procura entender como o cenário político brasileiro é apresentado nas páginas d'A carteira do meu tio. Em outras palavras, nosso principal intuito é apresentar, a partir da leitura desta obra o significado atribuído por Macedo à política da conciliação, bem como, os traços característicos da elite política imperial e, por fim, os obstáculos que impediam o desenvolvimento pleno da cena pública brasileira.

A consolidação de um público-leitor regular para os livros de viagem no Brasil oitocentista esteve, em grande medida, relacionada à ampliação da oferta desse tipo de 
publicação no país, favorecida pela Abertura dos Portos - medida decretada por D. João, em 1808 , que concedeu livre circulação aos visitantes estrangeiros no território brasileiro ${ }^{2}$ - e da instalação de instituições que fomentavam a difusão da cultura escrita, como a Impressão Régia e a Biblioteca Real (depois Nacional), a nosso ver, motivou - entre outros fatores - a opção de Macedo pelo gênero de viagem para dar voz às suas críticas em relação à política imperial.

Havia certo consenso entre os homens de letras que os relatos de viagem produzidos a partir de expedições científicas fossem fundamentais para o desenvolvimento das ciências naturais no Brasil, no entanto, havia uma preocupação com o gosto dos leitores que, em geral, prefeririam textos mais amenos, que proporcionassem o divertimento, mas sem abrir mão da instrução, ou seja, textos que fossem capazes de "instruir divertindo" ou "divertir instruindo". Nesse sentido, a opção pelas narrativas de viagem ficcionais era mais eficaz, no que tange à difusão dos saberes, pois a abordagem de temas caros à nação era feita de maneira sutil, sem deixar de proporcionar ao leitor um momento de deleite.

Macedo, em A carteira do meu tio, preocupou-se em retratar a realidade política do país, mas, de forma divertida, de modo que o autor se apropriou de um gênero de sucesso - a literatura de viagem - para trazer aos leitores seu ponto de vista sobre os homens públicos e a inaplicabilidade das leis. $O$ sobrinho foi obrigado pelo tio a viajar pelo território brasileiro, pois este acreditava que a viagem era parte da preparação para a carreira política, desejada pelo sobrinho. Inconformado com a ordem do tio, o jovem pensou em burlar as regras estabelecidas pelo seu mantenedor; para tanto, fingiria ter viajado e escreveria meia dúzia de histórias na carteira, para que o tio não suspeitasse da fraude.

Em um súbito momento de lucidez, o sobrinho "picareta" desiste da ideia de inventar seu relato - mesmo sabendo que "as narrações de todos os colegas viajantes, e principalmente daqueles, que têm andado pela nossa boa terra, contêm mais patranhas e mentiras" - e decide atender ao pedido do tio, comprometendo-se apenas a falar a verdade: "decidido de pedra e cal a seguir os conselhos de meu tio, escrevendo na carteira, que ele me confiou, verdade e só verdades", obtidas através da observação - do "ver com os próprios olhos" (MACEDO, 1855, p. 24). Desse modo, Macedo acaba por pontuar o objetivo d'A carteira do meu tio, cuja pretensão era apresentar as "reais" mazelas sociais e os desvios da política brasileira e não as paisagens naturais que eram comuns às narrativas de viagem sobre o Brasil.

A carteira do meu tio foi editada no jornal carioca $A$ Marmota Fluminense, dirigido pelo famoso tipógrafo Paula Brito. Entre os meses de janeiro e outubro de 1855, a viagem do sobrinho pelo território brasileiro era lançada na parte superior da primeira página do periódico, enquanto que nesse mesmo período, no espaço do folhetim (ou seja, no rodapé),

2 Tal permissão, como apontado anteriormente aumentou o número de viajantes estrangeiros no território brasileiro, consequentemente o Brasil passou a figurar em um número maior de livros de viagem, uma vez que a viagem está associada à escrita. Trata-se, portanto, de um período muito rico em se tratando de narrativas do gênero sobre o país. 
foram publicados os romances Vicentina e Oforasteiro, ambos de Joaquim Manuel de Macedo. Em 19 de janeiro de 1855, quando se publicava pela primeira vez a viagem do sobrinho, o redator d'A Marmota fez questão de diferenciar A carteira dos outros romances de Macedo:

Enquanto os jornais diários, cada vez mais importantes, satisfazem seus programas comerciais, e dizem-nos hoje muitas coisas sobre história, ciências, belas letras, etc.; $A$ Marmota vai de dia em dia conquistando a posição a que aspira, à custa de acurado trabalho e penosos sacrifícios, e é assim que tem conseguido elevar o número de seus assinantes à soma que felizmente já conta hoje. [...].

Para o desenvolvimento das letras a redação não duvida empenhar-se a fim de conseguir importantes trabalhos originais de penas brasileiras; $\mathrm{e}$ dar-se por feliz podendo dar hoje começo à belíssima história joco-séria da - CARTEIRA DO MEU TIO - além do novo romance do Sr. Dr. Macedo, que principiará talvez na terça-feira. (MARMOTA FLUMINENSE, 19 jan. 1855)

A justificativa apresentada pelo jornal evidenciou a preocupação de seus diretores em trazer ao conhecimento do público carioca textos de autores nacionais, uma vez que boa parte dos folhetins ${ }^{3}$ publicados por outros periódicos famosos - como o Diário do Rio de Janeiro e o Correio Mercantil - eram de autores franceses, como Eugène Sue e Alexandre Dumas. No entanto, devemos nos perguntar por que Paula Brito diferenciou $A$ carteira dos romances e optou por editá-la na parte superior do jornal e não no rodapé. Acreditamos que a explicação está relacionada ao teor do relato de viagem do sobrinho. Pela primeira vez, a engenhosa pena de Macedo abdicava das histórias de amor - característica de seus romances anteriores - para narrar a viagem de um personagem insolente e preguiçoso que pretendia ser político para não ter que trabalhar e que, diante de sua escolha, foi obrigado por seu tio a peregrinar pelo território brasileiro a fim de observar os reais problemas do país. Além disso, naquele contexto político - o período da conciliação -, no qual as críticas eram apresentadas de forma velada, as memórias do sobrinho denunciavam o cenário político brasileiro de forma sutil, irônica e alegórica, sem nomear e ofender diretamente a nenhum dos partidos e homens públicos, contribuindo para o posicionamento político dos leitores da folha, que apesar da predileção pela literatura, não se esquivava das discussões políticas e caras à época,

\footnotetext{
${ }^{3} \mathrm{O}$ termo "folhetim" tem origem na palavra francesa feuilleton, derivada de feuillet, cujo significado é pequena folha. No começo do século XIX, le feuilleton designava a parte inferior da primeira página dos jornais, o rodapé, espaço dedicado ao entretenimento, no qual se publicavam receitas de bolo, piadas, adivinhações, comentários críticos de peças teatrais e livros. Era um espaço aberto para os escritores neófitos se aventurarem, enfim para aquilo que divertisse o público. Na década de 1830, o termo folhetim passou a designar o "romance-folhetim".
} 
especialmente, quando literatura e política estavam intimamente relacionadas, como em $A$ carteira do meu tio.

Uma segunda hipótese - que não necessariamente exclui a primeira - estaria relacionada à intenção de atrair os leitores dos romances macedianos, porque, a esta altura de sua carreira, o autor havia consolidado seu nome entre os literatos brasileiros e com sua fama os jornais angariavam novos assinantes. Macedo também poderia estar preocupado em oferecer ao fiel público de suas histórias de amor um pouco de sua veia crítica - afinal, os leitores d'A Semana ${ }^{4}$, provavelmente, não eram os mesmos d'A Moreninha. Há de se convir que as críticas presentes em $A$ carteira eram reiteradas nas crônicas dominicais d'A Semana, o que nos permite aventar a ideia de que o autor desejava expressar seus princípios políticos utilizando diferentes linguagens e formas.

A narrativa de viagem do sobrinho também foi publicada na Província de Santa Catarina. Entre agosto e outubro, o primeiro folheto saiu à luz no espaço do folhetim no jornal $O$ conservador e o segundo folheto saiu em $O$ Argos, entre março e junho de 1856, ambos os periódicos dirigidos por José Joaquim Lopes e editados na tipografia que levava seu nome. $O$ fato de $A$ carteira do meu tio neste jornal ter aparecido no espaço dedicado ao folhetim reforça seu caráter ficcional, no entanto sua matéria o filiava à tradição dos textos de sátira política, cuja comicidade levavam os leitores ao riso e os fatos à reflexão social.

Desse modo, entendemos que $A$ carteira do meu tio é uma narrativa de viagem ficcional, na qual "ao real cabe o papel de ornamento" e à verossimilhança, o "estatuto de credibilidade" (CRISTÓVÃO, 2002, p. 51). A fim de questionar a própria estrutura do gênero, o relato do sobrinho subverteu características inerentes às narrativas de viagem tradicionais, bem como, propôs uma reflexão sobre o quadro político brasileiro à época. As impressões do jovem aspirante a homem público evidenciaram um mundo conhecido e partilhado por Macedo e seus leitores, cujo caráter ficcional da obra não excluiu a inserção de elementos da "vida real".

Nesse caso, a preocupação de Macedo era expor os labéus da política nacional, organizada a partir de um pacto conciliatório que enfraquecia os partidos políticos e procurava reduzir a pó as divergências entre eles. As impressões da viagem do sobrinho remontam às principais características da política no Brasil, bem como denunciam a inaplicabilidade das leis e os ideais que moviam o homem público no país. Trata-se, portanto, de um retrato da política e das tradições culturais, a partir da "apropriação de ideias e de palavras" (MACHADO \& PAGEAUX, 2001, p. 44-45) que são conhecidas pelos leitores e pelo próprio Macedo, que a esta altura já era um político bem-sucedido no império.

O feito literário de Macedo foi articular a literatura de viagem à sátira política, na esteira do que fizeram outros grandes autores, como Jonathan Swift, em Viagens de Gulliver;

${ }^{4}$ A Semana era o título do espaço destinado às crônicas dominicais no Jornal do Commercio. Macedo assumiu esta coluna em abril de 1854 e esteve à frente dela até 1859 . 
Montesquieu, em Cartas persas; e Tomás Antônio Gonzaga, em Cartas chilenas. À época, a nova produção macediana era caracterizada por sua "veia satírica". Paula Brito, por exemplo, no final de 1854, noticiou que no ano seguinte $A$ Marmota publicaria $A$ Carteira, que segundo o redator era uma "importante obra joco-séria, de uma das nossas mais agradáveis penas [...], obra que deve fazer bulha em todo o Império". O texto prometia causar uma bulha, ou seja, uma confusão, porque se tratava, segundo o próprio Paula Brito, de uma "engenhosa sátira, política, civil e administrativa, em interessantes diálogos entre o Sobrinho do Tio, o seu compadre Paciência, e algumas outras personagens" (MARMOTA FLUMINENSE, 28 out. 1854).

Em outros jornais, como o Correio da Tarde (em 22 de novembro de 1855) e o Correio Mercantil (em 26 de novembro de 1855), os anúncios sobre a obra - recém-lançada em livro apresentavam-na como uma "sátira oposicionista" que tocava em pontos delicados da nossa política, na qual constava uma "série infinita de carapuças sobre tudo e para todas as cabeças, talhadas como o espírito e a graça que caracterizavam os escritos da delicada pena de tão engenhoso escritor". Em tese, toda sátira faz oposição a algo, uma vez que sua natureza é justamente a censura dos costumes, pessoas e fatos históricos, porém, caracterizar a nova produção de Macedo como uma "sátira oposicionista", estava em consonância com o momento político que o país vivia, cuja política de conciliação, liderada pelo marquês de Paraná, buscava estreitar os laços entre os partidos liberal e conservador, apaziguando os ânimos e desmobilizando a oposição dos luzias ao governo.

Dois traços, portanto, definiam a obra de Macedo: seu tom satírico e suas alegorias "carapuças que serviriam a qualquer um", de acordo com as palavras do editor d'A Marmota, de modo que as personagens representam um determinado grupo social, como o sobrinho que retratava a forma de pensar e agir de uma parte da classe política imperial. Em última instância, A carteira do meu tio ironizava o estado da política brasileira no século XIX sob o disfarce do divertimento e, nesse sentido, Macedo não poderia ter escolhido melhor gênero para compor suas críticas, porque a literatura de viagem, além de apreciada pelos leitores, era capaz de "instruir divertindo" e de retratar (criticar), com ares de verdade, uma dada realidade, a partir das impressões do sobrinho do tio e do compadre Paciência - que, de algum modo, representam as opiniões do próprio Macedo.

Os dicionários do século XVIII e do início do século XIX apontam para o caráter censurador da sátira, definindo-a como uma "composição poética, inventada para emendar costumes depravados, ou para censurar e criticar obras de engenho" (BLUTEAU, 1728). Tratase, portanto, de obra destinada à crítica, e que, malgrado as definições setecentistas apontarem para a forma poética, é um gênero multiforme (ROCHA, 2006, p. 13), cujo objetivo é atacar algo através da ridicularização de suas características. De acordo com Sylvia Talarolli (1999, p. 66), a partir do século XIX, "a sátira não sobrevive mais propriamente como um gênero, mas se configura como uma atitude, uma forma de olhar, que se manifesta em 
qualquer modalidade de texto (prosa, poesia, teatro, pintura, escultura)" e, por que não, na literatura de viagem?

No século XIX, de acordo com George Minois, “é na sátira política que o riso encontra seu terreno predileto", porque os debates parlamentares e a liberdade de imprensa favorecem o debate de ideias, "no qual a ironia é chamada a desempenhar um papel essencial" (MINOIS, 2003, p. 482). Mesmo quando trata de assuntos sérios, a sátira moderna é capaz de suscitar o riso, só que um riso pragmático, ou seja, com uma finalidade clara: a de instruir. Desse modo, o "riso gratuito não tem mais lugar ou, pelo menos, passa a ser desprestigiado pelos filósofos, escritores e pensadores". O riso, conquistado por meio da sátira, assume papel pedagógico, nas palavras de Minois:

[...] tornou-se uma faculdade de espírito, uma ferramenta intelectual, um instrumento a serviço de uma causa moral, social, política, religiosa ou antirreligiosa. Ele se decompôs em risos mais ou menos espirituais, risos (MINOIS, 2003, p. 482).

O caráter "joco-sério", como caracterizou Paula Brito, d'A carteira do meu tio contempla esse papel pedagógico assinalado por Minois. Em última instância, Macedo desejava pôr em discussão questões importantes relacionadas à inaplicabilidade das leis constitucionais, o falseamento do sistema representativo no país e o andamento da política de conciliação que estava em curso desde 1853. Temas delicados, mas que o autor os abordou de forma humorada.

Se considerarmos sua trajetória pessoal, Macedo era um observador privilegiado, pois, como homem público, ele tinha condições de expor os valores e os acordos que engendravam seu funcionamento. Por meio de alegorias, o escritor esboçou os meandros da política nacional que ele observava no dia a dia de sua atuação política, como deputado da Assembleia Provincial que transitava entre os círculos dirigentes do Império. Com efeito, o escritor, assim como a geração a qual pertencia, acreditava que por meio de sua literatura e de sua atuação legislativa contribuiria para a construção nacional. Um projeto tão audacioso exigia um meio de comunicação de largo alcance - a imprensa - e um tipo de literatura que entretesse, mas, sobretudo, ensinasse valores morais adequados a uma grande nação. Nesse sentido, a crônica hebdomadária e a literatura de viagem tiveram lugar de destaque na produção literária de Macedo, no decorrer da década de 1850. Estes dois gêneros vincularam as críticas do autor ao sistema político-partidário e às práticas políticas que caracterizavam a cena pública brasileira.

A imprensa foi decisiva na formação dos costumes, do pensamento social e da consciência histórica oitocentista, sendo, portanto, um elemento ativo no processo histórico. 
Tal abordagem se assemelha à de Robert Darnton em seus estudos sobre o papel da tipografia no contexto da Revolução Francesa, no qual o historiador buscou entender a palavra impressa como um "ingrediente" do acontecimento, ou seja, como "força ativa na história" e não apenas como um registro do que aconteceu durante a Revolução. Segundo Darnton, "para tomar o poder tem que tomar a palavra e difundi-la", o que torna a tipografia "o principal instrumento na criação de uma nova cultura política" (DARNTON, 1996, p.15-16).

A atividade impressa no Brasil, no decorrer do século XIX, esteve intimamente ligada ao campo político e seu desenvolvimento foi concomitante à criação de espaços de discussão política. Desse modo, os periódicos, produzidos em um contexto de liberdade de expressão, contribuíram para a formação da esfera pública ${ }^{5}$.

O historiador Marco Morel, ao analisar o surgimento de uma modernidade política no Brasil, ressalta que o período entre 1820 e 1840 foi extremamente agitado e, portanto, propício para que tal processo se efetivasse. A partir dos estudos de Habermas acerca da esfera pública, Morel propôs três interpretações deste conceito, tendo em vista a realidade brasileira oitocentista: primeiro, salienta que a esfera pública não se confunde com o Estado; segundo, a esfera literária e cultural não está apartada da sociedade e é resultado "da expressão letrada ou oral dos agentes históricos diversificados"; e, por fim, trata-se, igualmente, de "espaços físicos ou locais onde se configuram estas cenas e esferas" (MOREL, 2005, p. 18).

No caso brasileiro, o Rio de Janeiro teve papel de destaque para a formação de uma esfera pública no país, uma vez que, na condição de capital imperial, passou a reverberar propostas políticas para todo o território e discutir os princípios liberais e as experiências políticas advindas da América do Norte e da Europa.

A imprensa foi crucial para a ampliação do saber no Rio de Janeiro e inconcebível seria pensar o desenvolvimento da cultura e da ciência de forma eficaz sem ela. Malgrado o país, antes mesmo da instalação dos prelos, possuir uma (pequena) elite instruída e familiarizada com a cultura escrita - impressa na Europa e introduzida nos trópicos muitas vezes por contrabando -, o seu alcance era pequeno e a interlocução entre os alfabetizados foi restrita. A presença da imprensa, nesse sentido, ampliou o gosto pelo saber e o acesso de um públicoleitor mais amplo a este suporte.

\footnotetext{
5 Jürgen Habermas aponta que a esfera pública é uma categoria histórica que se relaciona com o universo da burguesia, uma vez que, esta classe social formava um público letrado, num período em que o desenvolvimento da imprensa facilitou a difusão de ideias acerca de assuntos de interesse geral, inclusive debates em torno das ações do Governo. Trata-se, portanto, de um processo de publicização dos atos políticos institucionais, dando ao público informações sobre o andamento da vida política nacional, bem como, condições para que questionasse determinadas práticas de seus governantes. Desse modo, o surgimento de uma esfera pública representa o nascimento de um espaço de discussão a fim de se estabelecer certo consenso acerca das questões políticas que envolvem a cena pública. A esfera pública, portanto, compunha-se por pessoas que se reuniam para discutir questões privadas, mas que tinham relevância pública. (HABERMANS, 2003a, p. 74).
} 
No Segundo Reinado, os homens de letras, transidos do arcabouço romântico, acreditavam que a existência da nação requeria uma literatura e uma historiografia nacional (RICUPERO, 2004, p. 86). Para tanto, era necessário compor um grupo de literatos brasileiros que trabalhassem em torno de uma produção literária original e do aumento da atividade impressa no país. Os esforços dessa incipiente intelectualidade ampliaram significativamente o número de leitores regulares, graças à oferta de impressos, com destaque para o periodismo.

A partir da década de 1830, a inserção sistemática de textos literários na imprensa em geral ampliou a possibilidade de ensinar valores e práticas sociais aceitáveis a um número maior de leitores, sobretudo, ao público feminino. $\mathrm{O}$ romance era visto como um instrumento útil para a formação moral do leitor, bem como fomentava o gosto pela leitura, estimulando, assim, a aquisição da competência leitora responsável por um processo de transformação sócio-político, do qual emanam cidadãos mais críticos.

A literatura nacional, inserida paulatinamente nos periódicos, dialogava com o restante do jornal, pois também refletia os anseios e os problemas da jovem nação, sendo a expressão do "caráter do povo". Desse modo, esta produção literária, aliada a outros fatores, foi responsável pela organização da esfera pública, na medida em que atuava, também, como a manifestação de uma opinião pública, que foi construída a partir do debate público em torno de assuntos que dizem respeito à nação.

No século XIX, o livro, em geral, era o fim da trajetória literária de um texto ficcional, porque os literatos publicavam suas histórias de forma seriada primeiro nos jornais, e depois de aceitas pelo público-leitor e pela crítica especializada, eram convertidas em livros. $\mathrm{O}$ romance-folhetim fomentou o apreço pela leitura, mesmo em um período no qual o índice de alfabetizados era restrito e, muito importante, tornou-se um veículo de formação cultural, moral e política. O filósofo francês Denis Diderot acreditava que o romance era mais eficaz na formação moral dos indivíduos do que os manuais de conduta, devido à capacidade de emocionar o leitor e envolvê-lo na trama, de modo que este criasse empatia com os personagens virtuosos, rejeitando os imprudentes e desvirtuados (AUGUSTI, 1998).

Macedo foi um dos precursores do romance no Brasil. A Moreninha além de atrair o gosto dos leitores por este gênero, também marcou, definitivamente, as características desse tipo de produção. A crítica especializada oitocentista reconheceu as contribuições de Macedo para a literatura nacional. O crítico Reinaldo Gomes em 1858, por exemplo, escreveu um artigo para o Diário do Rio de Janeiro, no qual fez um panorama da história da literatura brasileira em que reconhece o legado de Macedo. Para ele: 
O Sr. Manuel de Macedo quis ser romancista e fundou o romance nacional, [...]. A mão augusta que no Brasil protege as ciências, enobreceu o peito deste homem de letras, que animando-se, deu o exemplo da iniciativa à mocidade que ia lançar-se mão na carreira do progresso moral. [...] com razão devemos chamá-lo de um exemplo fecundo, surgiram de toda a parte obras novas, talentos jovens, que vieram pedir a auréola da glória de um público que já tem o sentimento da arte em todas as suas especialidades. (DIÁRIO DO RIO DE JANEIRO, 29 set. 1858)

O grande feito do autor d'A Moreninha foi produzir textos que conciliavam, com maestria, o entretenimento e as questões da vida cotidiana, sem abdicar do caráter pedagógico-moral, expresso pela capacidade de apresentar o meio - onde se ambientava a trama - e pela linguagem acessível. Por estas razões, nas décadas de 1840 e 1860, Macedo publicou sistematicamente na imprensa periódica. Com um estilo característico, seus textos publicados entre folhetins, crônicas e peças teatrais - contribuíram, decisivamente, para a formação de um público-leitor regular e a consolidação do romance-folhetim e da crônica que, na ocasião da edição d'A Moreninha, ainda dava os primeiros passos - como gêneros literários do século XIX.

Com um público-leitor regular, facilitada com a explosão de jornais na capital do Império, Macedo acreditava que sua produção literária era uma poderosa arma de combate, um meio de instrução e, como tal, não poderia estar apartada da realidade, pelo contrário, ela tinha que "chamar a atenção pública para a consideração dos males que assaltam a sociedade" (A NAÇÃO, 07 jul. 1852). Por meio da imprensa, o escritor de Itaboraí defendeu os projetos de reforma apresentados por seus correligionários, bem como manifestava, sempre que podia, o apreço pelas ideias liberais.

Entre os anos de 1852 e 1854, ou seja, período em que o escritor pleiteava uma vaga na Assembleia Provincial, passou a editar, em parceira com Francisco Sales Torres Homem, uma folha política intitulada $A$ Nação. Macedo imprimia os exemplares em sua própria casa e seu projeto era, provavelmente, dar continuidade a outra publicação liberal - $A$ Reforma ${ }^{6}$ - que havia encerrado seus trabalhos no início de 1852. Certamente, o trabalho em A Nação deu projeção política a Macedo, contribuindo para o sucesso de sua candidatura em 1854, dada a importância da imprensa na formação da cena política brasileira e da opinião pública.

O envolvimento de Macedo com a política marcou, decisivamente, sua produção literária nos anos de 1850. As crônicas de $A$ Semana e $A$ carteira do meu tio são emblemáticas nesse

6 A Reforma foi lançada em 20 de setembro de 1851 e pertencia a Luís Antônio Navarro de Andrade. A redação do jornal era de responsabilidade de três figuras ilustres do jornalismo brasileiro: Francisco Sales Torres Homem, Antônio Manuel de Campos Melo e Gabriel José Rodrigues dos Santos. Entretanto, o periódico teve vida curta, no ano seguinte, por causa de desentendimentos entre os redatores, sua publicação foi suspensa. (SOUSA, 1963, p. 115-139). 
sentido, porém, outros textos produzidos nessa década também nos ajudam a pensar sobre o posicionamento político do autor, como é o caso da peça teatral $A$ torre em concurso (1857) e, claro, dos artigos de $A$ Nação.

Em A carteira do meu tio, especificamente, é possível observar a presença de duas vozes: a do narrador-sobrinho debochado, que apresenta seus distorcidos valores, e a do narradorautor que pretende examinar criticamente a situação política do país. ${ }^{7}$ Para Jefferson Cano, "o sobrinho é claramente aquele personagem-narrador que mais se distancia do autor" (CANO, 2004, p. 13).

De acordo com Temístocles Linhares, tanto em A carteira do meu tio quanto em Memórias do sobrinho do tio "Macedo traça a psicologia do político brasileiro com bastante segurança, com tantos elementos de verdade que muito pouco há a lhe acrescentar ou suprimir ainda em nossos dias". Em ambas, ele conseguiu retratar o homem público "em seus fundamentos humanos, em sua caça às posições e aos cargos”. (LINHARES, 1958, p. 97-98).

Nos diálogos entre o sobrinho e o compadre Paciência, ou entre o sobrinho e o tio fica evidente o conflito de opiniões, desse conflito emergem duas vozes ábsonas que, em última instância, são as do próprio autor. Macedo, ao apresentar essas duas vozes antagônicas conseguiu diferenciar a boa e a má política, ou ainda, o político de princípios e o egoísta. Este aspecto pode ser comprovado em duas passagens do livro, a saber: a primeira, quando os viajantes são acolhidos pelo Sr. Constante em sua hospedaria e, durante uma conversa, antes de servir o jantar, ele insistia em perguntar aos novos hóspedes sobre a novidades da capital. O sobrinho, irritado e com fome, respondeu que a corte passava por uma crise ministerial devido aos abusos e à violência, nas palavras do jovem: "abri a boca, e disse tudo, que me veio à cabeça: chamei de ladrões e celerados a todos os ministros, um por um" (MACEDO, 1855, tomo II, p. 22). A retaliação veio rapidamente, o estalajadeiro acusou o sobrinho de ser "inimigo do governo" e defendeu o ministério como "um deputado da maioria". Logo, o jovem caiu em si e reconheceu "a arma terrível que tem um estalajadeiro para empregar contra os seus adversários políticos" e, como se não tivesse alternativa, se "arrependeu" do discurso de oposição proferido ao Sr. Constante - especialmente, porque o dono da hospedagem se vingava atrasando o jantar:

Essa dualidade de vozes também é encontrada em $O$ Sobrinho de Rameau, de Denis Diderot. Trata-se de uma sátira em que Diderot, se valendo da tradição dialógica, passeia com argúcia e bom humor pelos mais variados temas, como a educação das crianças, a importância do dinheiro, o papel dos gênios e artistas na sociedade, a ética e a moral, dentre outros. Tais temas aparecem por meio de um diálogo entre $\mathrm{Eu}$, um filósofo (que não deve ser identificado inteiramente com Diderot) e Ele, um parasita da alta roda, boêmio excêntrico e contraditório, que "combinava altivez e vileza, bom senso e desvario". Há certa semelhança entre a proposta literária de Diderot e Macedo, pois na obra do escritor de Itaboraí o diálogo é entre o Sobrinho do Tio e o Compadre Paciência e o próprio tio. Cf. TELES, Edson, Introdução. In: DIDEROT, Denis. $O$ sobrinho de Rameau. Trad. Bruno Costa. São Paulo: Ed. Hedra, 2006.

${ }^{8}$ Memórias do Sobrinho é a obra que dá continuidade a história do sobrinho, e foi publicada por Macedo em 1868. 
Tempo perdido! Oito horas e meias, e nem os pratos da mesa! Oh que fome! $\mathrm{O}$ maldito estalajadeiro punha em horríveis pratos a minha firmeza de princípios; declaro francamente, que me arrependi de me haver mostrado oposicionista. (MACEDO, 1855, tomo II, p. 24).

A segunda, na qual o sobrinho, depois fazer uma longa explanação sobre a ausência de bom senso nos homens do governo, deu-se conta de que falava como o compadre Paciência e não como seus mestres:

Isto mesmo que acabo de escrever n' $A$ carteira do meu tio há de ficar muito em segredo; porque aliás seria um verdadeiro comprometimento para mim; pois que falei na linguagem do compadre Paciência, e não segundo as lições da escola que sigo. É que me lembrando do tal bom senso, fico fora de mim e digo asneiras. (MACEDO, 1855, tomo II, p. 22).

Essas duas vozes se alternam ao longo de toda a obra, uma representada pelo sobrinho "impostor e atrevido" e a outra pela do homem de letras Macedo, que em alguns momentos expressa suas opiniões pessoais - encontradas explicitamente em outros textos dele, como as crônicas d'A Semana - por meio das falas do tio e do compadre Paciência. Flora Sussekind, ao analisar as Memórias do sobrinho do meu tio, comentou que era comum o autor inserir "notas autocríticas" em seus textos narrados em primeira pessoa. De acordo com a pesquisadora, é como se ele emprestasse ao sobrinho-narrador "alguns dos principais temas do debate político", nos quais estava envolvido e se esforçasse em disseminá-los no desenrolar de sua obra de ficção (SUSSEKIND, 2011, p. 9-12). A única nota de rodapé que aparece em $A$ carteira do meu tio, por exemplo, expressa claramente a intenção da obra:

O autor desse livro está convencido, de que na Província do Rio de Janeiro, a mais civilizada do Império, não se observam fatos como esse, que aí vai imaginado; mas desgraçadamente em outras Províncias, e com especialidade em algumas do Norte, têm tido lugar não poucos atentados tão honrosos como esse; e pois que está no pensamento do autor atacar os abusos, e a desmoralização, acredita ele, que pode bem supor praticados nesta ou naquela Província, onde fizer viajar seu herói, as ilegalidades e os crimes, que em qualquer outra parte do Império se tem observado (MACEDO, 1855, tomo I, p. 99). 
Com efeito, o autor constrói uma ponte entre o elemento ficcional e a realidade brasileira, marcada pela relação antagônica entre as duas vozes narrativas. Os juízos, trazidos à luz pela segunda voz acerca do sistema político, desmontam o ficcionismo do sobrinho-narrador 9 Dessa dicotomia entre o discurso debochado e o tom sério e direto a obra atinge sua função educativa, quase panfletária. Ademais, por meio do jogo de vozes ábsonas, o leitor é convidado por Macedo a construir, de acordo com seus próprios valores, um parecer sobre os temas discutidos ao longo do enredo. Em A carteira do meu tio, a nosso ver, o autor abordou esses temas e estruturou o texto em três eixos: o corrompido caráter dos políticos da nação, a inaplicabilidade das leis constitucionais e a política de conciliação adotada pelo gabinete Paraná, em 1853.

O caráter corrompido da classe política brasileira é apresentado logo no início da narrativa, quando o sobrinho afirma seguir os passos dos mestres, cuja política se baseia no "EU". Cabe lembrar, a motivação do sobrinho para empreender uma viagem pelo território brasileiro: tratava-se de uma imposição do tio diante da decisão do jovem pela carreira política, já que o mantenedor obrigava-o a escolher uma carreira depois de seu retorno da Europa. Ao manifestar a decisão de seguir pela vida pública, o sobrinho justificava sua escolha definindo-a como comum aos "vadios de certa classe", ou seja, àqueles que, assim como a personagem, não estavam dispostos a trabalhar com afinco pela nação, mas gostariam de "viver à custa dela" (MACEDO, 1855, tomo I, p. 9).

Ser político era, portanto, um "modo de vida" e o sucesso nessa carreira dependia da capacidade do homem público de "ser cata-vento e ter os pés sempre prontos para quebrar os degraus, por onde subir, assim que não precisar mais deles" (MACEDO, 1855, tomo I, p. 83). Duas características, de acordo com o jovem, marcavam a política à época: o interesse e a indiferença, especialmente, entre os grupos dirigentes que balizam suas ações tendo em vista seus interesses pessoais. Para o sobrinho e seus mestres é fundamental que um estadista saiba selecionar suas companhias, aproximando-se de quem possa lhe dar algum tipo de vantagem, mas, também, deve saber descartá-las quando já não conseguir tirar nenhum proveito da aproximação. Nesse cenário político, marcado pelo interesse e pela indiferença, os dirigentes partidários ao invés de darem um "bom exemplo", de acordo com o narrador, são aqueles que mais se aproveitam das circunstâncias e das pessoas:

Os chefes dos partidos, que são a cabeça, exceção feita a meia dúzia de homens sinceros e dedicados, que todos respeitam, são egoístas e

\footnotetext{
9 Malgrado o sobrinho manter uma retórica da sinceridade - "Eu digo as cousas como elas são" -, comum aos viajantes, esta expressa em tom de galhofa e, por isso, o texto de Macedo consegue extrair do leitor aquele riso espontâneo, fruto da narração de um jovem "impostor e atrevido" em contraponto com o discurso moralizante de uma segunda voz.
} 
ambiciosos, cujos princípios políticos se resumem todos ao pronome $\mathrm{EU}$-; trabalham só a favor de seus interesses materiais, lutam e fazem lutar os outros só para se verem ocupando altas posições sociais, que lhes deem muito dinheiro e importância social. Para eles a política não passa de uma guerra de ambições ignóbeis, que se define perfeitamente com estas palavras, já muito repetidas: "desce tu, que eu quero subir". (MACEDO, 1855, tomo I, p. 87).

O sobrinho aponta o egoísmo como um traço característico de boa parte dos homens públicos no Brasil, por isso é que o personagem vai dizer que os políticos locais resumem seus princípios no pronome $E u$. Nesse sentido, em um artigo de $A$ Nação, Macedo afirmou que aqueles que procedem segundo as leis do Eu evidenciam a "estabilidade de seus princípios", pois:

No seu código particular, no alcorão de sua moral, existem princípios e regras inalteráveis: a política de Alexandre VI e os seus escrúpulos, parece que serviram de norma para a confecção dessa lei satânica, que aconselha 'sempre esta lei máxima terrível - "o fim justifica os meios, e todos os meios são bons para se chegar ao fim". (A NAÇÃO, 02 set. 1852).

Em $A$ carteira do meu tio, o sobrinho reconheceu que estes meios atentam contra a dignidade humana, porém ele não vê isso como um problema, pelo contrário, "os fins justificam os meios, e o mais é peta" (MACEDO, 1855, tomo II, p. 78). A máxima maquiavélica é, segundo o autor, um traço definidor do modo de se fazer política no Brasil, bem como a mentira e corrupção são inerentes aos homens públicos, com exceção, claro, de alguns poucos que trabalham em prol do desenvolvimento da nação.

Entre os parlamentares brasileiros uma prática tornou-se habitual: a troca de partidos, cuja ocorrência demonstra a preponderância da "troca de favores" em detrimento do alinhamento ideológico. Nosso insolente narrador atribuiu esta prática ao que ele designou por "política da barriga":

[...] os heróis que mudam de partido e se prendem ao carro ministerial pelos laços das tripas, id est, pela influência da fome, mostram-se fiéis e dedicados enquanto o ministério lhes conserva as pitanças; mas, logo 
que sentem, que lhes faltam, ou que as rações diminuem, ou que outros estômagos são mais bem aquinhoados do que os seus, põem a boca no mundo, largam o carro no caminho e tornam a levantar furiosa gritaria. (MACEDO, 1855, tomo II, p. 39-40).

De forma irônica, o sobrinho constata que os interesses são a mola propulsora da política no Brasil, porém, o ilustre aspirante a homem público não vê nenhum problema em pensar assim, pelo contrário, é justo que um "servo da nação" tire dela proveito e, para tanto, faz-se necessário ser apadrinhado por alguém que já esteja "em cima". Em contraste com a fala do sobrinho, o compadre Paciência apresentou sua visão acerca do assunto, as conclusões são parecidas com as do companheiro de viagem, contudo, ele não idealiza tal comportamento, pelo contrário ele define, em tom de desdém, aqueles que o cometem como "coche pequeno", alguém sem efetiva importância:

[...] a razão da alta gritaria, [...], que fazem aqueles que fazem da política seu meio de vida, aqueles que sobem os degraus por onde sobem as primeiras posições oficiais, aqueles que atraiçoam os partidos, que os seguiram, e que os elevaram como seus chefes, aqueles que de tempo em tempo mudam de princípios e de opinião, como as cobras mudam de pele, aqueles que como papagaios falam muito, quando tem fome, e calam-se logo que tem a barriga cheia, [...] a razão da gritaria e do espalhafato, [...], está em ser coche pequeno, e não poderem todos comerem ao mesmo tempo dentro dele. (MACEDO, 1855, tomo I, p. 96-97).

As características elencadas por Paciência, certamente, definiam um grupo significativo de políticos, porém, o autor d'A carteira certamente ao ironizar esse tipo de político em sua sátira tinha em mente alguns de seus ex-companheiros de partido, como é o caso de Antônio da Silva Limpo de Abreu.

Ironicamente, o sobrinho atribuiu as trocas partidárias à fome, "a mais poderosa das alavancas políticas, e a barriga dos adversários políticos é a Sebastopo $l^{10}$, contra a qual deve um ministério sábio e adestrado acertar toda a sua artilharia." Pelo excerto fica claro que o alvo preferencial dos membros da oposição é a "barriga", para tanto, o governo tem a seu favor o poder, com o qual joga a fim de conquistar os adversários para suas trincheiras. Afinal,

10 O Cerco de Sebastopol foi o principal combate ocorrido durante a Guerra da Crimeia, tendo durado de setembro de 1854 a setembro de 1855 . Os principais jornais do Rio de Janeiro noticiaram os desdobramentos do conflito e deram ênfase ao episódio citado por Macedo em A carteira do meu tio. 
"poucas barrigas resistem a um assédio feito em regra, e a um assalto dado oportunamente: toda a dificuldade está em descobrir-se o ponto fraco da fortaleza, de fazer-lhe aí a brecha" (MACEDO, 1855, tomo II, p. 32).

As constantes trocas de partidos políticos são o espectro, em linhas gerais, de uma política baseada na troca de favores, da falta de definição política e da ausência de debates mais ideológicos, sobre ética e sobre o bom funcionamento do sistema representativo. A cultura do apadrinhamento político no Brasil acabava atraindo para o ofício um bando de aventureiros e sanguessugas que estavam em busca de poder, independente dos meios que se tenha que optar para alcançá-lo. Nesse cenário, a conciliação é extremamente favorável, uma vez que se passa a defender um governo e não um partido. Em uma política conciliada deve-se baixar as bandeiras políticas em nome do "bem-estar nacional", foi esta a direção sinalizada pelo presidente do Conselho ao Senado, em setembro de 1853:

[...] o gabinete nada tem com o passado, os seus membros não se consideram nem como luzias, nem como saquaremas, estão todos de acordo em administrar o país segundo as necessidades atuais.

Portanto aqueles que apoiam e compartilham o pensamento do ministério são ministerialistas, qualquer que tenha sido ou seja seu partido; e os que não apoiam e compartilham este pensamento, não sendo os mais aptos para executá-lo, não podem ser nomeados para os empregos políticos. (MACEDO, 1855, tomo II, p. 32).

Com efeito, a nova cena política que se construía, na década de 1850, com o ministério presidido por Carneiro Leão tinha por objetivo abrandar as disputas partidárias, limitando o espaço de atuação da oposição. Para Macedo, a política de conciliação franqueou a troca de partidos como uma prática natural, justificável e até necessária para o progresso da nação, mascarando o egoísmo de nossos políticos e a fragilidade do debate sobre o sistema representativo e o cumprimento das leis constitucionais no país. Por meio da fala do sobrinho, o escritor ironizou esta situação:

Quem tiver fome, não se envergonhe de ir vender a sua opinião, e sacrificar os seus princípios a troco de um prato da mesa ministerial; por que tudo isso se explicará convenientemente. As palavras compra e venda não serão por certo empregadas, e o faminto, que se deixou conquistar pela política da barriga, em vez de dizer: "desertei de minhas fileiras", 
"bandeei-me", "atraiçoei minhas bandeiras", pode muito bem exclamar com um angélico sorriso nos lábios: "fiz uma conciliação". (MACEDO, 1855, tomo II, p. 38).

O escritor ressentia-se pela mudança partidária de alguns correligionários em nome da conciliação, especialmente Limpo de Abreu e Paranhos, antigos liberais; enquanto Torres Homem, articulador desta política, passou a flertar com os conservadores e nunca mais saiu do meio saquarema. Macedo reiterava que a conciliação deturpava a essência do sistema representativo, uma vez que pretender sufocar as organizações partidárias seria um absurdo, causando a anomalia do modelo democrático no Brasil. De acordo com o literato, "os partidos políticos nascem da própria natureza do sistema, são seus filhos, fazem parte da sua vida" (A NAÇÃO, 24 nov. 1852). ${ }^{11}$

Em uma conversa, o sobrinho pediu ao compadre que definisse os dois partidos a fim de que pudesse escolher qual fileira iria integrar. Paciência, então, começou a compará-los a um animal, composto por "três entidades": a enorme cauda que representa a multidão; o corpo formado pelos "correligionários pensantes"; enquanto a cabeça, uma minoria, são os chefes. Quando o bicho se desespera, a cauda assume o comando e leva a cabeça para "onde lhe parece". Entretanto, segundo Paciência, o problema da multidão é sua passividade, pois, enquanto cauda, "não sabe, nem procura saber, o que quer: segue o movimento que lhe imprime a cabeça" (MACEDO, 1855, tomo I, p. 85-86). O corpo, por sua vez, produz ideias convenientes ao país, mas "são idealistas, são poetas" e por isso, acabam se tornando vítimas dos mandatários dos partidos. Por fim, a cabeça, que tem o controle das outras entidades, é movida pelos interesses pessoais, "lutam e fazem lutar os outros só para se verem ocupando altas posições sociais, que lhes deem dinheiro e importância pessoal". (MACEDO, 1855, tomo I, p. 86-87).

A comparação com o corpo do animal denota que a estrutura e os métodos de ambos os partidos eram semelhantes: uma elite dirigente que conduz a agremiação, uma elite pensante que produz conhecimento e o resto que é conduzido pelos que estão acima. Contudo, ideologicamente, havia alguma diferença entre saquaremas e luzias? De acordo com Paciência:

O corpo de um proclama, que quer conservar, bem que vá, pelo sim pelo não, destruindo muita coisa boa; e o corpo do outro assevera, que quer

\footnotetext{
${ }^{11}$ Em outro artigo, Macedo asseverou: "Os partidos políticos são da essência do sistema representativo; entram na sua vida, e por isso mesmo que lhe são absolutamente necessários, tem também seus direitos nele. Lembremos o primeiro destes direitos. Os partidos políticos pedem e devem trabalhar por subir ao poder a fim de governar o país segundo suas ideias." (A NAÇÃO, 11 dez. 1852).
} 
progredir. Os conservadores dizem que não admitem o progresso político, porque temem que ele nos atire além dos limites da prudência: os progressistas repelem os erros do passado; sustentam que o sistema representativo está falseado entre nós, e que é indispensável apelar para as diversas reformas políticas, se quisermos que a monarquia constitucional seja no Brasil uma realidade: uns com os outros, conservadores e progressistas, dizem ainda muita coisa, mas o essencial é isto. (MACEDO, 1855, tomo I, p. 88).

Como se vê, o compadre distinguiu saquaremas e luzias a partir da dicotomia: "conservar x reformar", um lugar-comum à época para se definir os dois partidos políticos do Segundo Reinado. No entanto, entre os dirigentes partidários, com exceção "dos poucos que são sinceros e dedicados", não há engajamento ideológico, e por isso, no que tange aos princípios políticos "eles são idênticos", e podem ser resumidos, segundo Paciência, no "pronome Eu". Desse modo, a corrupção da moralidade política acontece entre os chefes dos partidos, uma vez que, enquanto a elite pensante mantém-se arraigada aos seus princípios - e por isso é idealista -, os chefes se transmutam facilmente.

Em setembro de 1853, D. Pedro II nomeou Carneiro Leão para a presidência do Conselho de Ministros, dando-lhe a missão de articular as reformas e promover o diálogo entre os dois partidos. A valer, durante o gabinete Paraná foram discutidos dois projetos reformistas - um em 1854 e outro em 1855 -, mas apenas um obteve vitória. Ao fim e ao cabo, a intervenção do monarca garantiu a abertura de uma nova cena política. Entretanto, não significa que a conciliação foi fruto exclusivo da ação do monarca; a nosso ver, a política conciliatória se beneficiou de outros dois fatores: a articulação dos liberais para retornar ao governo e, por fim, a crise interna entre os membros do partido conservador que demandava uma solução urgente - ou haveria um racha definitivo, com a formação de um terceiro partido.

Desde o início dos debates em torno da conciliação, Macedo via a proposta com desconfiança - inclusive, chegou a afirmar que "era o mecanismo mais suave; mas também o mais incerto, ou o menos realizável" (A NAÇÃO, 16 abr. 1853). Com o passar dos meses, a implicância do autor em relação à política de Carneiro Leão aumentou, e em pouco tempo, Macedo passou a criticá-la em seus artigos de $A$ Nação, nas crônicas hebdomadárias d'A Semana e nos textos ficcionais e teatrais, como $A$ carteira do meu tio e $A$ torre em concurso. $\mathrm{O}$ escritor alegava que o gabinete não estava cumprindo seu programa de governo e que a conciliação estava restrita a um grupo seleto de políticos conservadores, definidos por ele como "os amigos arrufados, entre os membros do mesmo partido que [hoje] domina", enquanto: 
[...] aquele que se acha em oposição, esse que sofra a gema, esse que continue a ser vítima da opressão dos senhores feudais das províncias, esse que viva ainda a vida dos proscritos. [...] Quando nas primeiras semanas que se seguiram à organização do atual gabinete, vimos um, ou dois, ou três dos nossos aliados escolhidos para alguns empregos, nos protestamos logo que não entendíamos a conciliação de certos indivíduos, mas de partidos, que não queríamos que se entendesse só ao mérito de um ou outro dos nossos, mas sim que abrisse francamente o campo a opinião liberal, que se desse a nação liberdade plena para se pronunciar que a convidasse a pronunciar-se e mais nada. (A NAÇÃO, 8 mar. 1854)

Outro aspecto da conciliação com o qual Macedo se incomodava era o "clima apartidário" que se queria construir com a nova política. Em nome da conciliação as bandeiras deveriam ser abaixadas, o importante passava a ser a nação e não os partidos. Enquanto boa parte dos homens públicos pareciam querer camuflar sua filiação partidária, o autor sempre que podia a reafirmava:

O Sr. Macedo: - [...] repito e declaro que, membro firme e decidido do partido liberal, adoto com o maior prazer essa reforma [eleitoral], e que ostento esse prazer, e por consequência não posso me afligir com o triunfo dessas ideias, que fazem parte dos princípios do meu partido.

Um Sr. Deputado: - Hoje não há partidos.

O Sr. Macedo: - Eu persisto nos meus principios: digo hoje, o que sempre me ouvistes; os nobres deputados modificaram um pouco suas ideias, e estão agora comigo?...

Um Sr. Deputado: - Foi passo para lá, passo para cá.

O Sr. Macedo: - Sr. presidente, eu desejo muito maior harmonia entre todos os brasileiros [...]. (DIÁRIO DO RIO DE JANEIRO, 5 set. 1855).

No ano anterior, Macedo teve um entrevero com um colega deputado que havia dito que não existiam "minorias", depois da política de conciliação:

Outro Sr. Deputado - Aqui não há maioria nem minoria. Só temos em vista o interesse da província (Apoiados). 
O Dr. J. M. de Macedo - Os nobres deputados desejam mostrar que não há maioria...

Um Sr. Deputado - Eu digo que não há.

Outro Sr. Deputado - Depois da conciliação não há minorias.

O Sr. J. M. de Macedo - Aí está o nobre deputado empregando uma palavra que não posso deixar passar despercebida. Senhores é verdade, no meio de tanta conciliação, pode por ventura haver minoria? Não é possível; quando muito poderá haver algum protesto simples e fraco; pode-se levantar uma ou outra voz, como a minha para opor-se a esta ou aquela medida, mas voz que não tem significação alguma, principalmente porque parte de quem não tem bastante força para convencer.

Senhores se pudesse haver luta, o requerimento de adiantamento partiria de mim; [...]. A matéria é especial; muito especial, e não poderei entrar nela por falta de conhecimentos. Se entender dever falar, eu o falarei. (DIÁRIO DO RIO DE JANEIRO, 24 ago. 1854).

O escritor não se calou diante da falácia de que as minorias estavam extintas com a conciliação. E, como já era de costume, Macedo se colocava com uma voz destoante, parte de uma "minoria" que, ainda, ousava levantar suas bandeiras, marcando posição dentro do sistema político. A resposta também serviu como uma "lição de moral" aos colegas parlamentares que, por vezes, votam em uma determinada matéria sem ter a menor ideia do seu conteúdo e sem ponderar seus efeitos para a sociedade. Em última instância, esse tipo de deputado deliberava novas leis de acordo com as "ordens de cima", demonstrando incompetência, despreparo e irresponsabilidade.

Com efeito, a própria ideia de conciliação para o escritor era incompatível com o sistema representativo, que deveria ser alimentado pelo debate de ideias. Desse modo, não era um problema ser oposicionista, pelo contrário, nos países democráticos e que adotam o bipartidarismo era "natural" que um partido sustentasse o Governo, e que outro o combatesse. Em suas palavras:

[...] no sistema representativo a nação governa a si mesma pela opinião que predomina e triunfa; e como não se pode admitir que os cidadãos de um Estado tenham todos os mesmos princípios [pois] não há triunfo de opinião sem combate à opiniões, não há nem pode haver sistema 
representativo, onde não há certame e oposição de partidos. (MACEDO, 1863, p. 115).

Como liberal, Macedo esperava que a conciliação garantisse maior espaço ao seu partido dentro das instituições políticas, contribuindo para fomentar o debate acerca dos projetos de reforma, cuja origem era atribuída por ele aos correligionários de seu partido desde a década de 1840. A expectativa do escritor se cumpriu, ao menos em parte, porque por mais que os idealizadores da política de conciliação buscassem arrefecer as agruras entre saquaremas e luzias; os projetos de reforma - judiciária e eleitoral - apresentados no decorrer do gabinete Paraná fomentaram intensos debates entre os ministros, deputados e senadores. Consequentemente, ao invés de um período de calmaria política ${ }^{12}$, ele assistiu a acaloradas discussões entre os parlamentares, mesmo que estes adotassem um discurso apartidário e evitassem ataques pessoais na tribuna. Talvez, nesse sentido, a conciliação tenha sido bemsucedida, afinal a oposição ao governo, entre 1853-1857, partiu dos dois lados.

A nosso ver, a nova política implantada em 1853 pelo Gabinete Paraná era, na verdade, uma manobra liberal para retornar à cena pública a fim de movimentar as discussões acerca dos projetos de reforma apresentados pelo luzias na década anterior. $\mathrm{O}$ autor d'A carteira do meu tio era um entusiasta de tais projetos, especialmente, os que reviam a estrutura do poder judiciário e o sistema eleitoral brasileiro. No entanto, como parte da historiografia demonstrou, a política de conciliação também sinalizou uma maior interferência do imperador D. Pedro II na política nacional.

Em seus escritos políticos, Macedo esboçou o cenário de crise que se instalava entre os membros do Partido Conservador, sobretudo, entre suas principais lideranças que estavam em desacordo com o gabinete de Joaquim José Rodrigues Torres e ameaçavam separar-se dos saquaremas para fundar o Partido Parlamentar. Nesse sentido, a política conciliatória também evitaria um racha interno entre os conservadores.

Na visão de Macedo a mácula do sistema político brasileiro era a falta de fidelidade partidária, que seria facilitada com a conciliação, já que a trégua imposta aos partidos justificaria a migração de políticos liberais para as fileiras conservadoras, e vice-versa. Além disso, nossas leis estavam no limbo e a maneira como o sistema eleitoral estava estruturado impediam que houvesse eleições livres e a ascensão de candidatos pouco conhecidos ou

12 Joaquim Nabuco, em Um estadista no império vê o gabinete Paraná como um período de paz, no qual "se obliteraram inteiramente as divisas entre os partidos". (NABUCO, p. 174). Essa ideia que reaparece no trabalho de Sérgio Buarque de Holanda caracterizou o período da conciliação como o tempo das "águas paradas", devido ao entibiar dos partidos políticos. (HOLANDA, 2010, p. 105). Contudo, por mais que a política de conciliação pretendesse estabelecer a coalizão entre os partidos, ela não promoveu, efetivamente, um período de paz, como assinala Bruno Estefanes. (ESTEFANES, 2015). 
desapadrinhados. Nesse contexto, as bandeiras da reforma política e da moralização dos homens públicos tonaram-se para o escritor um fardo a ser carregado.

Referências

\section{Periódicos oitocentistas:}

A MARMOTA NA CORTE. Rio de Janeiro: Typ. de Paula Brito, 1849-1852. . Rio de Janeiro, 1849-1853.

A NAÇÃO. Rio de Janeiro: Typ. da Nação de J. M. de Macedo, Covill e Cia, 1852-1854.

CORREIO BRASILIENSE, ou Armazém Literário. Londres: W. Lewis, 1808-1822.

CORREIO MERCANTIL: e instructivo, politico, universal. Rio de Janeiro: [s.n.]

DIÁRIO DE ANNUNCIOS. Rio de Janeiro: Typ. de Lena \& Pereira, 1833.

DIÁRIO DO RIO DE JANEIRO. Rio de Janeiro: Typ. do Diário, [1821-1878].

JORNAL DO COMMERCIO. Rio de Janeiro: Typ. de J. Villeneuve e C., 1833-.

MARMOTA FLUMINENSE: jornal de modas e variedades. Rio de Janeiro: Typ. Dous de Dezembro, de Paula Brito, 1852-1857.

MINERVA BRASILIENSE: jornal de sciencias, lettras e artes. Rio de Janeiro: Typ. de J. E. S. Cabral,1843-1845.

NITHEROY: revista brasiliense, sciencias, lettras e artes. Paris: Imprimerie de Beaule et Jubin, 1836.

O CONCILIADOR FLUMINENSE, o jornal politico, histórico e miscellanico. Rio de Janeiro: Typ. Fluminense de Brito e C./ Typ. do Diário, 1832.

O CORREIO DA TARDE: jornal politico, litterario e commercial. Rio de Janeiro: Typographia americana de I. P. da Costa, 1848-1859. 
O OSTENSOR. Rio de Janeiro, 1845.

\section{Textos setecentistas e oitocentistas:}

BLUTEAU, Raphael. Vocabulário português e latino. Coimbra: Colégio das Artes da Companhia de Jesus, 1717-1728.

MACEDO, Joaquim Manuel de. Memórias do sobrinho do meu tio. São Paulo: Penguin Classics Companhia das Letras, 2011.

_ _ _ _ _. Memórias da Rua do Ouvidor. Brasília: Edições do Senado, 2005.

_ _ _ _ _. Um passeio pela cidade do Rio de Janeiro. Brasília: Edições do Senado, 2005.

_ _ _ _ . A torre em concurso: comedia burlesca em tres actos. Rio de Janeiro: B. L. Garnier, 1863.

_. Chronica Politica. In: Bibliotheca Brasileira, 1863.

. A carteira do meu tio. Rio de Janeiro: Emp. Typ. Dous de Dezembro, 1855.

NABUCO, Joaquim. Um estadista no Império: Nabuco de Araújo, sua vida, suas opiniões, sua época. Tomo I (1813-1857). Rio de Janeiro: H. Garnier, s/d.

\section{Fontes publicadas:}

BRASIL. Anais da Câmara dos Deputados. Rio de Janeiro, 1848-1857. Disponível em: $<$ http://www.camara.gov.br>.

BRASIL. Anais do Senado. Rio de Janeiro, 1848-1857. Disponível em: $<$ http://www.senado.gov.br $>$.

COLEÇÂO Leis do Império do Brasil (1808-1889). Disponível em: <http://www.camara.gov.br>.

FALAS do Trono (1823-1889). Rio de Janeiro: Imprensa Nacional/Câmara dos Deputados, 1889. 


\section{Estudos:}

AUGUSTI, Valéria. O romance como guia de conduta: A Moreninha e Os dois amores. Campinas: IEL/UNICAMP, 1998.

BARMAN, Roderick J. Imperador cidadão. São Paulo: Ed. Unesp, 2012.

CÂNDIDO, Antonio. Formação da literatura brasileira: momentos decisivos 1750-1880. 11. ed. Rio de Janeiro: Ouro sobre Azul, 2007.

et al. A crônica: o gênero, sua fixação e suas transformações no Brasil. Campinas/Rio de Janeiro, Ed. da UNICAMP/Fundação Casa de Rui Barbosa, 1992.

CANO, Jefferson. Nas trilhas da crônica: literatura e imprensa no Rio de Janeiro do século XIX. (No prelo, cedido pelo autor).

A política da lusofobia: partidos e identidades políticas no Rio de Janeiro (18481849). Locus: Revista de História. Juiz de Fora: Editora UFJF, 2007, v.13, n.01.

(Organização e notas). Labirinto. Campinas: Mercado de Letras. Cecult; São Paulo: Fapesp, 2004.

_ _ _ _ . O fardo dos homens de letras: o orbe literário e a construção do império brasileiro. Tese de Doutoramento em História - Unicamp, Campinas, 2001.

CARDOSO, Marília Rothier. Moda da crônica: frívola e cruel. In: CANDIDO, Antonio et al. $A$ crônica: o gênero, sua fixação e suas transformações no Brasil. Campinas/Rio de Janeiro, Ed. da UNICAMP/ Fundação Casa de Rui Barbosa, 1992.

CARVALHO, José Murilo de. A Construção da Ordem E Teatro de Sombras. $2^{\circ}$ edição. Rio de Janeiro: Civilização Brasileira, 2008.

CRISTÓVÃO, Fernando (coord.). Condicionantes culturais da literatura de viagens: estudo e bibliografias. Coimbra: Almedina, 2002.

Literatura de viagens: da tradicional à nova e à novíssima - marcas e temas. Coimbra: Almedina, 2009.

DARNTON. Robert; ROCHE, Daniel (Orgs.). Revolução Impressa: a imprensa na França de 1775 a 1880. São Paulo: Edusp, 1996.

ESTEFANES, Bruno Fabris. Conciliar o Império: o marquês de Paraná e a política imperial, 18421856. São Paulo: Annablume, 2013. 
FERRAZ, Paula Ribeiro. O gabinete da conciliação: atores, ideias e discursos (1848-1857). Dissertação de Mestrado - Universidade Federal de Juiz de Fora, Juiz de Fora, 2013.

GINZBURG, Carlo. Mitos, Emblemas, Sinais: Morfologia e História. São Paulo: Companhia das Letras, 1991.

GUERRA, François-Xavier; LEMPÉRIÈRE, Annick et al. Los espacios públicos en Iberoamérica. Ambigüedades y problemas. Siglos XVIII-XIX. Cidade do México: Fondo de Cultura económica, 1998.

HABERMAS, Jürgen. Direito e democracia: entre facticidade e validade. Vol II. $2^{\circ}$ ed. Rio de Janeiro: Tempo Brasileiro, 2003b.

_ _ _ _ _ . Mudança estrutural da esfera pública. Rio de Janeiro: Tempo Brasileiro, 2003a.

HANSEN, João Adolfo. A anatomia da sátira. In: VIEIRA, Bruno V. G; THAMOS, Márcio. Permanência clássica: visões contemporâneas da Antiguidade greco-romana. São Paulo: Escrituras, 2011.

HODGART, Mattew. La sátira. Madrid: Ediciones Guadarrama, 1969.

HOLANDA, Sérgio B. de. Capítulos de História do Império. São Paulo: Companhia das Letras, 2010.

IGLÉSIAS, Francisco. Vida política, 1848-1868. In: HOLANDA, Sérgio B. (Org.). História Geral da Civilização Brasileira. Rio de Janeiro: Bertrand Brasil, 2004. Tomo II, vol. 5.

LIMA, Carollina Carvalho Ramos de. Os viajantes estrangeiros nos periódicos cariocas (18081836). Dissertação de Mestrado - Faculdade de História, Direito e Serviço Social, Universidade Estadual Paulista, Franca/SP, 2010.

LIMA, Carollina Carvalho Ramos de. A carteira do meu tio, de Joaquim Manuel de Macedo: literatura de viagem e sátira política em tempos de conciliação. Tese de Doutorado - Instituto de Estudos da Linguagem, Universidade Estadual de Campinas, Campinas/SP, 2015.

LINHARES, Temístocles. Macedo e o romance brasileiro. In: Revista do livro. Rio de Janeiro: 1958, n. 10.

MACHADO, Álvaro M; PAGEAUX, Daniel-Henri. Da literatura comparada à teoria literária. Lisboa: Ed. Presença, 2001.

MARSON, Isabel A. O império do progresso: a revolução praieira (1842-1855). São Paulo: Ed. Brasiliense, 1987. 
MARSON, Izabel A. Política, história e método em Joaquim Nabuco: tessituras da revolução e da escravidão. Uberlândia: EDUFU, 2008.

MARTINS, Lílian. História em revista. Dissertação de Mestrado - Faculdade de História, Direito e Serviço Social, Universidade Estadual Paulista, Franca/SP, 2009.

MATTOS, Ilmar R. O tempo saquarema. São Paulo: Editora Hucitec, 2004.

MEYER, Marlyse. Folhetim: uma história. São Paulo: Companhia das letras, 1966.

MINOIS, Georges. História do riso e do escárnio. São Paulo: Editora Unesp, 2003

MOREL, Marco. As transformações dos espaços públicos. Imprensa, atores políticos e sociabilidades na Cidade Imperial, 1820-1840. São Paulo: Hucitec, 2005.

MOREL, Marco; BARROS, Mariana M. de. Palavra, imagem e poder: o surgimento da imprensa no século XIX. Rio de Janeiro: DP\&A, 2003.

NEEDELL, Jeffrey D. The Party of Order: the Conservatives, the State, and Slavery in the Brazilian Monarchy, 1831-1871. Stanford/California: Staford University Press, 2006.

RICUPERO, Bernardo. O romantismo e a ideia de nação (1830-1870). São Paulo: Martins Fontes, 2004.

ROCHA, Débora Cristina Bondance. Bibliotheca Nacional e Pública do Rio de Janeiro: um ambiente para leitores e leituras de romance (1833-1856). Dissertação de Mestrado UNICAMP, Campinas, 2011.

ROCHA, Rejane C. Da utopia ao ceticismo: a sátira na literatura brasileira contemporânea. Tese de Doutorado - Universidade Estadual Paulista, Araraquara, 2006.

RODRIGUES, José Honório. Conciliação e Reforma no Brasil: um desafio histórico-político. Rio de Janeiro: Editora Civilização Brasileira, 1965.

SCHALCH, Laís. Um estudo dialético de A carteira do meu tio de Joaquim Manuel de Macedo. Dissertação de Mestrado - Faculdade de Filosofia, Letras e Ciências Humanas/USP, São Paulo, 2012.

SERRA, Tânia R. C. Joaquim Manuel de Macedo ou os dois Macedo: a luneta mágica do II Reinado. Rio de Janeiro: Fundação da Biblioteca Nacional, 1994.

SIMIONATO, Juliana S. A Marmota e seu perfil editorial: contribuição para edição e estudo dos textos machadianos publicados nesse periódico (1855-1861). Dissertação de Mestrado - Escola de Comunicações e Artes, São Paulo, 2009. 
SOETHE, Paulo Astor. Sobre a sátira:, 2003. contribuições da teoria literária alemã na década de 60. In: Fragmentos, n.25, Florianópolis: Universidade Federal do Paraná

SOUSA, Galante. Introdução ao estudo da literatura brasileira. Rio de Janeiro: Instituto Nacional do Livro, 1963.

SUSSEKIND, Flora. Introdução. In: MACEDO, Joaquim Manuel de. Memórias do sobrinho do meu tio. São Paulo: Pinguin Classics - Companhia das Letras, 2011.

_ _ _ _ _. O Brasil é longe daqui. São Paulo: Companhia das Letras, 1996, p.96.

TELAROLLI, Sylvia. Entre a fúria e a esperança, o fel e o riso: a presença da sátira na literatura brasileira. In: SEGATTO, José Antônio; BALDAN, Ude. Sociedade e literatura no Brasil. São Paulo: Editora Unesp, 1999.

Recebido em 12.06.2017

Aprovado em 07.08.2017 